\title{
Beef Tallow and Emulsifier in Growing-Finishing Pig Diets
}

\author{
KASSIA M. SANTOS ${ }^{1}$, PEDRO H. WATANABE ${ }^{2}$, EDNARDO R. FREITAS ${ }^{2}$, RAFAEL \\ C. NEPOMUCENO ${ }^{2}$, PAULA J.D. OLIVEIRA ${ }^{2}$, VIRGÍNIA M. LIMA ${ }^{2}$, BÁRBARA B.V. \\ RODRIGUES ${ }^{2}$, GERMANO A.J. DO NASCIMENTO ${ }^{2}$ and LUIZ E. DE CARVALHO ${ }^{2}$
}

\author{
${ }^{1}$ Universidade Estadual de São Paulo, Faculdade de Ciências Agrárias e Veterinárias, Via de \\ Acesso Paulo Donato Castelane, s/n, 14884-900 Jaboticabal, SP, Brazil \\ ${ }^{2}$ Universidade Federal do Ceará, Departamento de Zootecnia, Avenida Mister Hull, \\ 2977, Campus do Pici, Bloco 807, 60455-900 Fortaleza, CE, Brazil
}

Manuscript received on August 3, 2016; accepted for publication November 14, 2016

\begin{abstract}
Two trials were aimed to evaluate beef tallow in diets with and without emulsifier on performance of pigs at growing-finishing phases. In the first trial, 15 barrows $(22.03 \pm 0.62 \mathrm{~kg})$ were distributed among three treatments: reference diet; test diet 1 ( $5 \%$ beef tallow) and test diet $2(10 \%$ beef tallow). Beef tallow presented average value of $7130.97 \mathrm{kcal} \mathrm{ME} / \mathrm{kg}$. For the performance trail, 30 barrows $(24.85 \pm 1.18 \mathrm{~kg})$ were distributed among five treatments: T1 - diet with soybean oil and $3230 \mathrm{kcal} \mathrm{ME} / \mathrm{kg}$; T2 - diet with beef tallow and $3230 \mathrm{kcal} \mathrm{ME} / \mathrm{kg}$; T3 - diet with beef tallow and $3080 \mathrm{kcal} \mathrm{ME} / \mathrm{kg}$; T4 - diet with beef tallow, $3080 \mathrm{kcal} / \mathrm{kg}$ and $0.1 \%$ emulsifier; T5 - diet with beef tallow, $2930 \mathrm{kcal} \mathrm{ME} / \mathrm{kg}$ and $0.1 \%$ emulsifier. Feed conversion was worse in animals fed diet with $3080 \mathrm{kcal} \mathrm{ME} / \mathrm{kg}$ containing beef tallow and with 2930 $\mathrm{kcal} \mathrm{ME} / \mathrm{kg}$ with beef tallow and emulsifier. For economic availability, animals fed diet with beef tallow and $3230 \mathrm{kcal} \mathrm{ME} / \mathrm{kg}$ and those fed diet with $3080 \mathrm{kcal} \mathrm{ME} / \mathrm{kg}$ containing beef tallow and emulsifier, did not differ from animals fed diet with soybean oil, which enables the reduction up to $150 \mathrm{kcal} \mathrm{ME} / \mathrm{kg}$ be compensated by emulsifier addition.
\end{abstract}

Key words: animal fat, lipids, soy lecithin, triglycerides.

\section{INTRODUCTION}

Lipids are energy sources that have been included in pig diets due to the higher energy content and lower heat increment compared to carbohydrates, being the soybean oil the most widely used due to its availability and composition of long-chain unsaturated fatty acids, being more susceptible to the action of pancreatic lipase. However, the high

Correspondence to: Pedro Henrique Watanabe

E-mail: pedrowatanabe@ufc.br cost of soybean oil, as well as the offseason price variation motivates the search for alternative lipid sources, such as beef tallow, which is a residue derived from adipose tissue cavity and subcutaneous fat from cattle submitted to slaughter (Pupa 2004). Some studies showed the viability of tallow as a substitute for soybean oil in diets for pigs (Apple et al. 2009a, Park et al. 2009), as well as improving carcass fat quality (Browne et al. 2013).

However, the use of beef tallow is questioned in relation to its efficiency, due to the content 
of long-chain saturated fatty acids which not provide an appropriate relationship between saturated fatty acids and unsaturated fatty acids required for a synergistic response derived from this interaction, resulting in lower digestibility (Mitchaothai et al. 2008). In this sense, aiming to improve the digestibility of saturated fatty acids and the absorption of triacylglycerides, emulsifier additives can be added to diets containing beef tallow. Among the emulsifiers, soybean lecithin is a phospholipid which mode of action consists of reducing the surface tension of immiscible phases of lipids, increasing the digestibility of fat and other lipid compounds (Mitchaothai et al. 2010). Researches evaluating the use of emulsifiers in pig diets are scarce and mainly related to lipid sources of vegetable origin (Overland et al. 1993). In this sense, considering the lower cost of lipid sources such as beef tallow, these additives may be an important nutritional tool to maximize the use of triacylglycerides and reduce the cost of growingfinishing pig diets.

Based on the above, the objective of this research was to evaluate the effects of beef tallow in diets for growing-finishing pigs with or without the addition of emulsifier, on performance, nutrient digestibility of diets, serum triglycerides, carcass characteristics and economic viability.

\section{MATERIALS AND METHODS}

The experimental procedures followed the protocols approved by Ethics Committee on Animal Research (CEUA 144/2014) of Federal University of Ceará (UFC).

The experiment was conducted in the Pig Farming Sector of the Federal University of Ceará and divided into two trials; the first trial was aimed to determine the metabolizable energy and digestible nutrients from beef tallow and the second one to evaluate the inclusion of beef tallow with and without addition of emulsifier in diets for growing-finishing pigs.
The first trial was performed using 15 barrows from commercial line with initial weight of 22.03 $\pm 0.62 \mathrm{~kg}$, alloted in metabolic cages. The animals were distributed in a completely randomized design with three treatments and five replicates. The treatments were: RD - reference diet, TD1 - test diet composed by $95 \%$ reference diet and $5 \%$ of beef tallow and TD 2 - test diet composed by $90 \%$ of reference diet and $10 \%$ of beef tallow. The reference diet (Table I) was based on corn and soybean meal, formulated to meet the requirements of nutrients and metabolizable energy, according to the recommendations of Rostagno et al. (2011). Total collection of feces and urine method was performed, being the 12-day experimental period with seven days for adaptation to diets and cages and five days of collection of feces and urine. Samples were subsequent analyzed for dry matter (DM), mineral matter (MM), crude protein (CP), ether extract (EE) and gross energy (GE), according to AOAC (1995). After the analysis, it was obtained the coefficient of digestibility of nutrients and metabolizable energy of beef tallow (Sakomura and Rostagno 2007).

In the performance trial, a total of 30 barrows of commercial line, with initial weight of $24.85 \pm 1.18$ $\mathrm{kg}$, was distributed in a randomized block design, based on the initial weight, with five treatments and six replicates. The treatments were defined by isonutrient experimental diets (Table I), formulated according to the nutritional requirements for growing phase 1 (70 to 90 days of age), growing phase 2 (90 to 105 day old) and finishing phase (105 to 150 days of age), considering feedstuff composition as proposed by Rostagno et al. (2011). For beef tallow, energy value obtained in the metabolism trial was used. The experimental diets differed in lipid source, metabolizable energy level (ME) and with or without emulsifier addition, as follows: T1 - control diet with soybean oil inclusion and $3230 \mathrm{kcal} \mathrm{ME} / \mathrm{kg}$; T2 - diet with beef tallow inclusion and $3230 \mathrm{kcal} \mathrm{ME} / \mathrm{kg}$; T3 - diet with beef 


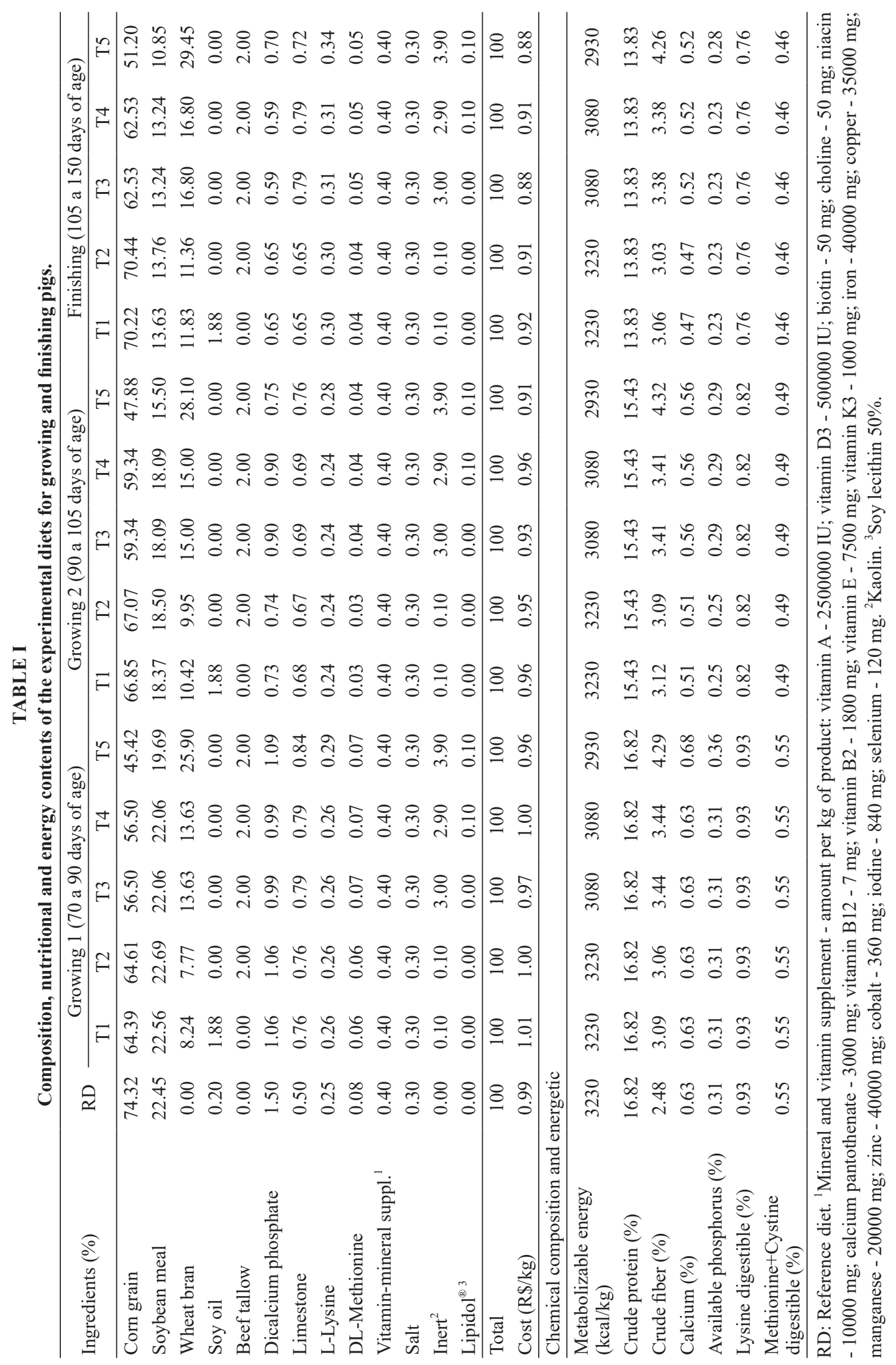


tallow inclusion and $3080 \mathrm{kcal} \mathrm{ME} / \mathrm{kg}$; T4 - diet with beef tallow inclusion, $3080 \mathrm{kcal} \mathrm{ME} / \mathrm{kg}$ and addition of $0.1 \%$ emulsifier; T5 - diet with beef tallow inclusion, $2930 \mathrm{kcal} \mathrm{ME} / \mathrm{kg}$ and addition of $0.1 \%$ emulsifier. It was used the emulsifier Lipidol ${ }^{\circledR}$, consisted of soy lecithin $(50 \%)$. Water and feed were offered ad libitum to the animals during all experimental period.

To measure the performance variables, the animals and diets were weighed at the beginning and end of each phase. The feed leftovers were collected and quantified daily to calculate the feed intake. Based on the data feed intake and weight of the animals, it was determined daily feed intake, daily weight gain and feed conversion ratio, considering the period 1 (70-90 days), period 2 (70105 days) and total period (70 to 150 days).

The coefficients of digestibility of nutrients and energy of diets were determined at the beginning of finishing phase, through the method of partial feces collection, being the Celite 545 used as an external marker. The adaptation period was represented by the first three days, followed by four days of feces collection, which are directly collected in the rectum of the animal, once a day. After the collection period, analyzes were performed for DM, MM, CP, EE, GE and acid insoluble ash (AIA) in faces samples and diets. The acid insoluble ash was determined by digestion in $4 \mathrm{~N}$ hydrochloric acid and burned in a muffle furnace according to the method of Van Keulen and Young (1977).

For serum triglycerides, blood collection was performed at 77, 97 and 112 days of age and analyzes were performed by enzymatic colorimetric method (Labtest Diagnostica).

At the end of experimental period, the animals were weighed and slaughtered after fasting for 15 hours, in a commercial slaughterhouse. After 24 hours, it was measured the carcass weight, carcass yield, carcass length, average backfat thickness, loin depth, fat depth, loin eye area and fat area and calculated the amount of lean meat, lean meat percentage and fat $/$ meat ratio, according to Bridi and Silva (2007).

Samples of the Longissimus muscle of the right half carcass, without the fat layer adjacent, were vacuum packed and stored in a freezer $\left(-10^{\circ} \mathrm{C}\right)$ for later determination of color (Minolta CR300 colorimeter, Tokyo), pH, water holding capacity, cooking loss, shear force and reactive substances to the 2-thiobarbituric acid (TBARS) according to Cherian et al. (2007).

To evaluate the economic viability, it was determined the cost of diet per kilogram of live weight gain, according to the equation proposed by Bellaver et al. (1985), calculating the economic efficiency index and the cost index, as proposed by Fialho et al. (1992). The allowance index was calculated from the lean meat percentage and the hot carcass weight, according to Bridi and Silva (2007). It was also determined the value of the pig at the beginning of the experiment, from the initial weight of the animal and the price per kilogram of live weight ( $\mathrm{R} \$ 6.70$ ), and at the end of the experiment, considering the allowance index and the hot carcass weight, being calculated the partial gross income and partial net income, considering the feed costs and the value of pig carcasses (Favero et al. 1997).

Data from both trials were submitted to analysis of variance by SAS statistical software. In the metabolism trial, the digestibility of crude protein, ether extract, mineral matter and energy values between 5 and $10 \%$ of beef tallow inclusion was compared. In the performance trial, means were compared by Dunnet test at $5 \%$ of significance. Serum triglycerides were analyzed in a split plot design, considering the treatments as plots and the collection time as subplots, and means compared by Dunnet test at $5 \%$ of significance.

\section{RESULTS AND DISCUSSION}

There was no difference between the digestible nutrients and metabolizable energy of beef 
tallow $(\mathrm{P}>0.05)$ in both levels of inclusion on metalizability trial (Table II).

The metabolizable energy value of beef tallow was lower than that indicated by Rostagno et al. (2011), which can be related to the lack of standardization of the feedstuff. The moisture content of the tallow remained below $1 \%$, being characterized as appropriate, considering that higher levels can result in a reduction of energy by dilution or by increasing free fatty acids, resulting in lower digestibility of the ingredient (Raber et al. 2009). The coefficient of metabolizability of beef tallow, obtained by the ratio of metabolizable and gross energy values, was $86.39 \%$, higher than the value of $83.82 \%$ found by Rostagno et al. (2011).

Regarding the performance (Table III), it was observed significant difference $(\mathrm{P}<0.05)$ for feed conversion ratio in the period 2 and total period among animals fed control diet, diet containing $3080 \mathrm{kcal} \mathrm{ME} / \mathrm{kg}$ with the inclusion of beef tallow without emulsifier and diet containing $2930 \mathrm{kcal}$ $\mathrm{ME} / \mathrm{kg}$ with beef tallow and emulsifier.

The inclusion of $2 \%$ of beef tallow on diet containing $3230 \mathrm{kcal} \mathrm{ME} / \mathrm{kg}$ in all phases, provided metabolizable energy needed for the development of the animals, resulting consequently in a performance similar to those obtained for pigs fed diets containing soybean oil with the same energetic level. The results agree with those obtained by Kim et al. (2008) that observed higher daily weight gain and better feed conversion ratio of growing pigs fed diets containing $2.5 \%$ beef tallow and soybean lecithin emulsifier, compared to those who received feed without this additive. Thus, the emulsifier addition and the energy density of the diet resulted in distinct effects, because, in this study, the energy of diet containing emulsifier was used by the pigs primarily to compensate the reduction of dietary energy density up to $150 \mathrm{kcal} \mathrm{ME} / \mathrm{kg}$, which may correct the nutritional matrix of this feedstuff from the use of this additive in pig diets.

The coefficients of digestibility of nutrients and energy of diets (Table IV) was higher in treatments containing the energy level of $3230 \mathrm{kcal}$ $\mathrm{ME} / \mathrm{kg}$, regardless of the lipid source, as well as in the treatment with a reduction of $150 \mathrm{kcal} \mathrm{ME} / \mathrm{kg}$ containing beef tallow and emulsifier $(\mathrm{P}<0.001)$.

Although it was not observed differences in the digestibility of nutrients and energy between the lipid sources in treatments containing 3230 kcal ME/kg (T1 and T2), Mitchaothai et al. (2008) observed higher coefficient of digestibility of ether extract and crude protein in diets containing sunflower oil compared to those containing beef tallow. Similarly, Duran-Montgé et al. (2007) observed that beef tallow showed lower ileal coefficient of digestibility when compared to lipid sources from vegetable origin for growing pigs. Regarding the emulsifier, the results agree with the performance of animals, because the lower digestibility coefficients found for the animals fed diet containing $3080 \mathrm{kcal} \mathrm{ME} / \mathrm{kg}$ and beef tallow

TABLE II

Nutritional and energetic composition of beef tallow in two evaluated levels for pigs at growing phase.

\begin{tabular}{|c|c|c|c|c|c|c|}
\hline \multirow[t]{2}{*}{ Composition (DM basis) } & \multirow[t]{2}{*}{ Chemical composition } & \multicolumn{3}{|c|}{$\begin{array}{c}\text { Digestible nutrients and } \\
\text { metabolizable energy }\end{array}$} & \multirow[t]{2}{*}{$\mathrm{CV}^{2}(\%)$} & \multirow[t]{2}{*}{$\mathrm{P}$ value } \\
\hline & & $5 \%$ & $10 \%$ & $\mathrm{BT}^{1}$ & & \\
\hline Dry matter $(\%)$ & 99.94 & 94.08 & 95.78 & 94.93 & 9.38 & 0.8995 \\
\hline \multicolumn{7}{|l|}{ Nutrients and energy } \\
\hline Crude protein (\%) & 0.03 & 0.00 & 0.01 & 0.005 & 1.54 & 0.5402 \\
\hline Ether extract (\%) & 99.96 & 93.96 & 94.53 & 94.24 & 8.77 & 0.5129 \\
\hline Mineral matter (\%) & 0.40 & 0.34 & 0.35 & 0.34 & 5.74 & 0.9304 \\
\hline Gross energy $(\mathrm{kcal} / \mathrm{kg})$ & 8254.02 & 7042.13 & 7219.81 & 7130.97 & 4.92 & 0.1867 \\
\hline
\end{tabular}

${ }^{1} \mathrm{BT}$ - beef tallow; ${ }^{2} \mathrm{CV}$ - coefficient of variation. 
TABLE III

Performance of pigs fed diets with variation in energy level, source of lipids, with and without emulsifier addition.

\begin{tabular}{|c|c|c|c|c|}
\hline Phase & Treatment & Daily feed intake $(\mathrm{kg})$ & Daily weight gain $(\mathrm{kg})$ & Feed conversion ratio \\
\hline \multirow{7}{*}{$\begin{array}{c}\text { Period } 1 \\
\text { (70 to } 90 \text { days) }\end{array}$} & $\mathrm{T} 1$ & $1.745 \pm 0.23$ & $0.793 \pm 0.12$ & $2.210 \pm 0.12$ \\
\hline & $\mathrm{T} 2$ & $1.803 \pm 0.16$ & $0.820 \pm 0.06$ & $2.196 \pm 0.08$ \\
\hline & $\mathrm{T} 3$ & $1.858 \pm 0.22$ & $0.811 \pm 0.06$ & $2.286 \pm 0.10$ \\
\hline & $\mathrm{T} 4$ & $1.802 \pm 0.18$ & $0.832 \pm 0.09$ & $2.168 \pm 0.07$ \\
\hline & $\mathrm{T} 5$ & $1.786 \pm 0.13$ & $0.767 \pm 0.04$ & $2.330 \pm 0.15$ \\
\hline & $\mathrm{CV}(\%)^{1}$ & 10.58 & 10.10 & 4.98 \\
\hline & $P$ value & 0.8861 & 0.7427 & 0.1488 \\
\hline \multirow{7}{*}{$\begin{array}{c}\text { Period } 2 \\
\text { (70 to } 105 \text { days) }\end{array}$} & $\mathrm{T} 1$ & $2.118 \pm 0.21$ & $0.880 \pm 0.08$ & $2.354 \pm 0.15$ \\
\hline & $\mathrm{T} 2$ & $2.093 \pm 0.20$ & $0.882 \pm 0.07$ & $2.370 \pm 0.08$ \\
\hline & $\mathrm{T} 3$ & $2.206 \pm 0.17$ & $0.869 \pm 0.02$ & $2.569 \pm 0.15^{*}$ \\
\hline & $\mathrm{T} 4$ & $2.130 \pm 0.14$ & $0.897 \pm 0.05$ & $2.373 \pm 0.04$ \\
\hline & T5 & $2.111 \pm 0.11$ & $0.815 \pm 0.05$ & $2.596 \pm 0.13 *$ \\
\hline & $\mathrm{CV}(\%)^{1}$ & 7.85 & 6.53 & 4.90 \\
\hline & $P$ value & 0.7362 & 0.1373 & 0.0035 \\
\hline \multirow{7}{*}{$\begin{array}{c}\text { Total period } \\
\text { (70 to } 150 \text { days) }\end{array}$} & $\mathrm{T} 1$ & $2.442 \pm 0.23$ & $0.902 \pm 0.07$ & $2.648 \pm 0.08$ \\
\hline & $\mathrm{T} 2$ & $2.412 \pm 0.22$ & $0.893 \pm 0.06$ & $2.645 \pm 0.09$ \\
\hline & $\mathrm{T} 3$ & $2.522 \pm 0.10$ & $0.869 \pm 0.02$ & $2.905 \pm 0.14^{*}$ \\
\hline & $\mathrm{T} 4$ & $2.465 \pm 0.07$ & $0.926 \pm 0.03$ & $2.662 \pm 0.05$ \\
\hline & T5 & $2.453 \pm 0.13$ & $0.872 \pm 0.05$ & $2.814 \pm 0.04^{*}$ \\
\hline & $\mathrm{CV}(\%)^{1}$ & 6.65 & 5.56 & 3.33 \\
\hline & $P$ value & 0.7913 & 0.3291 & 0.0001 \\
\hline
\end{tabular}

${ }^{1} \mathrm{CV}$ - Coefficient of variation; *Means followed by an asterisk in the column differ from the treatment $\mathrm{T} 1$ by Dunnet test at $5 \%$ of significance.

TABLE IV

Coefficient of digestibility of nutrients and energy of diets for pigs at growing phase, according to energy level, source of lipids, with and without emulsifier addition.

\begin{tabular}{lccccccc}
\hline \multirow{2}{*}{ Coefficient of digestibility } & \multicolumn{9}{c}{ Trataments } & \multirow{2}{*}{ CV $^{1}$ (\%) } & P value \\
\cline { 2 - 6 } & T1 & T2 & T3 & T4 & T5 & & 0.0001 \\
\hline Dry matter (\%) & 96.31 & 96.33 & $95.01 *$ & $95.47 *$ & $94.92 *$ & 0.36 & 0.0024 \\
Mineral matter (\%) & 68.59 & 66.82 & $63.69 *$ & 67.68 & $61.82 *$ & 4.20 & 0.0086 \\
Gross protein (\%) & 82.90 & 83.86 & $79.92 *$ & 81.56 & $78.73 *$ & 2.16 & 0.0086 \\
Ether extract (\%) & 71.71 & 72.79 & $58.02^{*}$ & 72.67 & $60.61 *$ & 7.22 & 0.0001 \\
Energy (\%) & 86.90 & 86.92 & $84.92 *$ & 85.68 & $82.72 *$ & 1.13 & 0.0001 \\
\hline
\end{tabular}

${ }^{1} \mathrm{CV}$ - Coefficient of variation; *Means followed by the asterisk in the line differs from treatment T1 by Dunnet test at $5 \%$ probability.

without adding emulsifier, as well as in those that were fed diets containing $2930 \mathrm{kcal} \mathrm{ME} / \mathrm{kg}$ containing beef tallow and emulsifier, resulted in worse feed conversion ratio of the animals.

Whereas the main effect of the emulsifier is related to better utilization of dietary lipids, it was observed that the inclusion of the additive resulted in the digestibility of the ether extract similar to the diet containing the soybean oil. Evaluating the addition of $1.5 \%$ of emulsifier in diets for pigs containing $6.5 \%$ of beef tallow, Reis de Souza et al. (1995) observed an increase in coefficient of digestibility of ether extract, although it was not observed the same effect in digestibility of energy. 
Similarly, Soares and Lopez-Bote (2002), observed that the addition of soybean lecithin in piglet diets containing different lipid sources, increased animal fat digestibility, because micelle formation from saturated fatty acids present in the fat is lower, and thus the emulsifier could potentiate the lipid digestion.

The levels of serum triglycerides (Table $\mathrm{V})$ did not differ among treatments $(\mathrm{P}>0.05)$, disagreeing with the results obtained by Park et al. (2009) who observed higher serum triglycerides levels in animals fed diets containing 5\% of beef tallow compared to those fed soybean oil, being the divergence justified by the different inclusion levels of beef tallow among studies. According to Klingenberg et al. (1995), the amount of carbohydrates in the diet is the main cause of hypertriglyceridemia, having no effect of lipid sources composed predominantly of C18:n in the diet on the level of plasma triglycerides.

There was no significant difference $(\mathrm{P}>$ $0.05)$ in carcass characteristics and meat quality among treatments (Table VI). Thus, the worst feed conversion ratio in animals fed diet containing $3080 \mathrm{kcal} \mathrm{ME} / \mathrm{kg}$ and beef tallow without emulsifier addition, and those fed diet containing

TABLE V

Serum triglycerides levels of pigs fed diets with variation in energy level, source of lipids, with and without emulsifier addition.

\begin{tabular}{cccc}
\hline \multirow{2}{*}{ Trataments } & \multicolumn{3}{c}{ Triglycerides $(\mathrm{mg} / \mathrm{dL})$} \\
\cline { 2 - 4 } & $\begin{array}{c}\text { Period } 1 \\
\text { (70 to } 90 \text { days })\end{array}$ & $\begin{array}{c}\text { Period } 2 \\
\text { (70 to 105 days) }\end{array}$ & $\begin{array}{c}\text { Total period } \\
\text { (70 to 150 days) }\end{array}$ \\
\hline T1 & 79.52 & 73.45 & 68.73 \\
T2 & 72.51 & 70.35 & 78.68 \\
T3 & 63.50 & 54.65 & 55.75 \\
T4 & 81.05 & 63.09 & 68.22 \\
T5 & 67.96 & 59.09 & 59.97 \\
\hline CV (\%) & 29.94 & 28.95 & 26.18 \\
P value & 0.6679 & 0.2391 & 0.3141 \\
\hline
\end{tabular}

${ }^{1} \mathrm{CV}$ - Coefficient of variation.

TABLE VI

Carcass characteristics and meat quality of pigs fed diets with variation in energy level, source of lipids, with and without emulsifier addition.

\begin{tabular}{|c|c|c|c|c|c|c|c|}
\hline \multirow{2}{*}{ Carcass characteristics } & \multicolumn{5}{|c|}{ Trataments } & \multirow{2}{*}{$\mathrm{CV}^{1}(\%)$} & \multirow{2}{*}{$P$ value } \\
\hline & $\mathrm{T} 1$ & $\mathrm{~T} 2$ & T3 & $\mathrm{T} 4$ & T5 & & \\
\hline Weight at slaughter (kg) & 97,03 & 95,62 & 94,78 & 94,48 & 95,04 & 4,48 & 0,1728 \\
\hline Hot carcass weight (kg) & 72,15 & 70,35 & 70,45 & 72,62 & 69,95 & 3,40 & 0,0357 \\
\hline Carcass yield (\%) & 74,42 & 73,68 & 74,36 & 74,53 & 72,82 & 3,00 & 0,9120 \\
\hline Carcass length $(\mathrm{cm})$ & 93,17 & 93,93 & 92,83 & 93,50 & 92,70 & 2,16 & 0,0714 \\
\hline Average backfat thickness (mm) & 24,51 & 24,22 & 25,25 & 23,30 & 21,72 & 15,56 & 0,3232 \\
\hline Loin depth (mm) & 63,17 & 60,06 & 60,98 & 59,17 & 60,82 & 7,07 & 0,4637 \\
\hline Fat depth (mm) & 14,30 & 14,56 & 13,41 & 12,52 & 10,76 & 27,81 & 0,4751 \\
\hline Carcass amount of lean meat $(\mathrm{kg})$ & 42,12 & 40,87 & 41,53 & 43,61 & 42,16 & 4,02 & 0,1392 \\
\hline Carcass lean meat percentage $(\%)$ & 58,02 & 57,56 & 58,32 & 58,63 & 59,82 & 3,82 & 0,6091 \\
\hline Loin eye area $\left(\mathrm{cm}^{2}\right)$ & 38,40 & 38,90 & 39,47 & 36,87 & 38,40 & 16,35 & 0,2334 \\
\hline Fat area $\left(\mathrm{cm}^{2}\right)$ & 17,07 & 15,50 & 17,22 & 15,76 & 12,68 & 20,68 & 0,0127 \\
\hline Fat/meat ratio & 0,46 & 0,44 & 0,44 & 0,42 & 0,34 & 19,84 & 0,3306 \\
\hline
\end{tabular}


TABLE VI (continuation)

\begin{tabular}{|c|c|c|c|c|c|c|c|}
\hline \multirow{2}{*}{ Carcass characteristics } & \multicolumn{5}{|c|}{ Trataments } & \multirow{2}{*}{$\mathrm{CV}^{1}(\%)$} & \multirow{2}{*}{$P$ value } \\
\hline & T1 & $\mathrm{T} 2$ & T3 & T4 & T5 & & \\
\hline$\overline{\mathrm{L}^{* 2}}$ & 58,57 & 57,94 & 59,31 & 58,4 & 57,98 & 3,64 & 0,8010 \\
\hline$a^{*^{3}}$ & 2,32 & 3,26 & 2,47 & 3,16 & 3,40 & 31,14 & 0,1699 \\
\hline $\mathrm{b}^{* 4}$ & 11,26 & 11,85 & 11,78 & 11,90 & 11,95 & 8,24 & 0,7339 \\
\hline $\mathrm{pH}$ & 5,80 & 5,70 & 5,75 & 5,82 & 5,76 & 1,77 & 0,2851 \\
\hline Water retention capacity $(\%)$ & 1,35 & 1,19 & 1,31 & 1,34 & 1,33 & 8,51 & 0,1285 \\
\hline Cooking loss $(\%)$ & 70,85 & 70,32 & 69,99 & 68,55 & 69,86 & 3,77 & 0,6438 \\
\hline Shear force $\left(\mathrm{kgf} / \mathrm{cm}^{2}\right)$ & 3,37 & 4,03 & 3,25 & 4,02 & 3,61 & 31,06 & 0,6615 \\
\hline TBARS $^{5}$ dia $0(\mathrm{mg} / \mathrm{kg})$ & 3,39 & 3,56 & 3,09 & 3,03 & 3,04 & 23,15 & 0,1053 \\
\hline TBARS dia 7 (mg/kg) & 6,70 & 6,99 & 6,03 & 6,48 & 6,89 & 19,38 & 0,1248 \\
\hline
\end{tabular}

${ }^{1} \mathrm{CV}$ - Coefficient of variation. ${ }^{2}$ Lightness. ${ }^{3}$ Redness. ${ }^{4}$ Yellowness. ${ }^{5}$ Thiobarbituric acid reactive substances.

$2930 \mathrm{kcal} \mathrm{ME} / \mathrm{kg}$, beef tallow and emulsifier, did not result in depreciation in carcass characteristics. Similar results to those found in this study were observed by Mitchaothai et al. (2007) comparing the beef tallow and sunflower oil as lipid sources for finishing pigs, as well as by Park et al. (2009), replacing soybean oil by beef tallow at $5 \%$ in barrow diets, noting similar values for loin depth and fat depth between treatments. Comparing beef tallow to used cooking oil, Browne et al. (2013) noted that both lipid sources in diets did not affect the carcass characteristics of pigs. Evaluating the beef tallow, palm oil and glycerol in diets for finishing pigs, Lee et al. (2013) observed that the beef tallow did not decrease carcass characteristics, although it has resulted in lower value of $\mathrm{L}^{*}$ value of fat. Considering that the addition of beef tallow in the diet can change the fatty acid profile of pork meat, increasing the composition of saturated fatty acids to the detriment of mono and polyunsaturated, and that the latter are amenable to peroxidation (Apple et al. 2009b), there was no effect of this ingredient and the emulsifier on the TBARS value of the meat.

According to the results of the economic evaluation (Table VII), the economic efficiency index, cost index and the partial net income was significantly lower $(\mathrm{P}<0.05)$ for animals fed diet containing $3080 \mathrm{kcal} \mathrm{ME} / \mathrm{kg}$ with beef tallow without emulsifier and those fed diet with 2930 $\mathrm{kcal} \mathrm{ME} / \mathrm{kg}$ containing beef tallow and emulsifier compared to animals fed diet with soybean oil. On the other hand, animals fed diet with beef tallow and $3230 \mathrm{kcal} \mathrm{ME} / \mathrm{kg}$ and those fed diet with 3080 $\mathrm{kcal} \mathrm{ME} / \mathrm{kg}$ containing beef tallow and emulsifier,

TABLE VII

Economic evaluation of pigs fed diets with variation in energy level, source of lipids, with and without emulsifier addition.

\begin{tabular}{lccccccc}
\hline \multirow{2}{*}{\multicolumn{1}{c}{ Variables }} & \multicolumn{9}{c}{ Treatments } & \multirow{2}{*}{ CV $^{1}$ (\%) } & P value \\
\cline { 2 - 6 } & T1 & T2 & T3 & T4 & T5 & & 0.7896 \\
Cost of feeding (R\$) & 185.91 & 181.75 & 184.26 & 185.95 & 177.09 & 7.98 & 0.0363 \\
Economic efficiency index & 97.17 & 97.19 & $92.04^{*}$ & 100.00 & $92.23^{*}$ & 6.13 & 0.0275 \\
Cost index & 100.00 & 101.76 & $107.25^{*}$ & 100.51 & $109.44^{*}$ & 6.49 & 0.5325 \\
Allowance index & 102.26 & 101.28 & 102.07 & 103.35 & 103.24 & 2.00 & 0.0429 \\
Partial gross income (R\$) & 290.28 & 275.65 & 279.20 & 304.16 & 273.50 & 5.92 & 0.0121 \\
Partial net income $(\mathrm{R} \$)$ & 112.53 & 113.48 & $95.64^{*}$ & 111.88 & $96.41^{*}$ & 9.26 & 0.26 \\
\hline
\end{tabular}

${ }^{1} \mathrm{CV}$ - Coefficient of variation; *Means followed by an asterisk in the line differs from treatment T1 by Dunnet test at $5 \%$ probability. 
did not differ from animals fed diet with soybean oil as lipid source.

The difference in economic efficiency index and cost index are related to the worst feed conversion ratio observed in treatments with beef tallow was the lipid source, with dietary energy level reduction of $150 \mathrm{kcal} \mathrm{ME} / \mathrm{kg}$ without emulsifier and reduction of $300 \mathrm{kcal} \mathrm{ME} / \mathrm{kg}$ with emulsifier. In this sense, emulsifier inclusion could compensate the reduction of $150 \mathrm{kcal} \mathrm{ME} / \mathrm{kg}$ but was not effective at higher energy reductions.

\section{CONCLUSIONS}

The beef tallow can substitute soybean oil as lipid source in diets for pigs at growing and finishing phases, and the reduction of up to $150 \mathrm{kcal} \mathrm{ME} /$ $\mathrm{kg}$ in diet within the use of beef tallow can be compensated by emulsifier addition.

\section{REFERENCES}

AOAC. 1995. Official methods of analysis. Association of Official Analytical Chemist, Washington D.C.

APPLE JK, MAXWELL CV, GALLOWAY DL, HAMILTON CR AND YANCEY JW. 2009a. Interactive effects of dietary fat source and slaughter weight in growingfinishing swine: III. Carcass and fatty acid compositions. J Ani Sci 87: 1441-1454.

APPLE JK, MAXWELL CV, GALLOWAY DL, HUTCHISON $\mathrm{S}$ AND HAMILTON CR. 2009b. Interactive effects of dietary fat source and slaughter weight in growingfinishing swine: I. Growth performance and longissimus muscle fatty acid composition. J Ani Sci 87: 1407-1422.

BELLAVER C, FIALHO ET, PROTAS JFS AND GOMES PC. 1985. Radícula de malte na alimentação de suínos em crescimento e terminação. Pesq Agropec Bras 20: 969974.

BRIDI AM AND SILVA CA. 2007. Métodos de avaliação de carcaça e da carne suína. Londrina: Midiograf, 97 p.

BROWNE NA, APPLE JK, BASS BE, MAXWELL CV, YANCEY JW, JOHNSON TM AND GALLOWAY DL. 2013. Alternating dietary fat sources for growing-finishing pigs fed dried distillers grains with solubles: I. Growth performance, pork carcass characteristics, and fatty acid composition of subcutaneous fat depots. J Ani Sci 91: 1493-1508.

CHERIAN G, TRABER MG, GOEGER MP AND LEONARD SW. 2007. Conjugated linoleic acid and fish oil in laying hen diets: effects on egg fatty acids, thiobarbituric acid reactive substances, and tocopherols during storage. Poult Sci 86: 953-958.

DURAN-MONTGÉ P, LIZARDO R, TORRALLARDONA D AND ESTEVE-GARCIA E. 2007. Fat and fatty acid digestibility of different fat sources in growing pigs. Livest Sci 109: 66-69.

FAVERO JA, GUIDONI AL AND BELLAVER C. 1997. Predição do índice de valorização de carcaças suínas em função do peso e do percentual de carne. In: CONGRESSO DA ASSOCIAÇÃO BRASILEIRA DE VETERINÁRIOS ESPECIALISTAS EM SUÍNOS, Anais... Concórdia: EMBRAPA-CNPSA, p. 405-406.

FIALHO ET, BARBOSA HP, FERREIRA AS, GOMES PC AND GIROTTO AF. 1992. Utilização da cevada em dietas suplementadas com óleo de soja para suínos em crescimento e terminação. Pesq Agropec Bras 27: 1467-1475.

KIM WT, SHINDE P AND CHAE BJ. 2008. Effect of lecithin with or without chitooligosaccharide on the growth performance, nutrient digestibility, blood metabolites and pork quality of finishing pigs. Can J Ani Sci 88: 283-292.

KLINGENBERG IL, KNABE DA AND SMITH SB. 1995. Lipid metabolism in pigs fed beef tallow or high-oleic acid sunflower oil. Comp Biochem Phys B 110: 183-192.

LEE JW, KIL DY, KEEVER BD, KILLEFER J, MCKEITH FK, SULABO RC AND STEIN HH. 2013. Carcass fat quality of pigs is not improved by adding corn germ, beef tallow, palm kernel oil, or glycerol to finishing diets containing distillers dried grains with solubles. J Ani Sci 91: 2426-2437.

MITCHAOTHAI J, YUANGKLANG C, WITTAYAKUN S, VASUPEN K, WONGSUTTHAVAS S, SRENANUL P, HOVENIER R, EVERTS H AND BEYNEN AC. 2007. Effect of dietary fat type on meat quality and fatty acid composition of various tissues in growing-finishing swine. Meat Sci 76: 95-101.

MITCHAOTHAI J, EVERTS H, YUANGKLANG C, WITTAYAKUN S, VASUPEN K, WONGSUTHAVAS S, SRENANUL P, HOVENIER R AND BEYNEN AC. 2008. Digestion and deposition of individual fatty acids in growing-finishing pigs fed diets containing either beef tallow or sunflower oil. J Ani Phys Ani Nutr 92: 502-510.

MITCHAOTHAI J, YUANGKLANG C, VASUPEN K, WONGSUTHAVAS S AND BEYNEN AC. 2010. Effect of dietary calcium and lecithin on growth performance and small intestinal morphology of young wild pigs. Livest Sci 134: 106-108.

OVERLAND M, TOKACH MD, CORNELIUS SG, PETTIGREW JE AND WILSON ME. 1993. Lecithin in swine diets: II. Growing-finishing pigs. J Ani Sci 71: 1194-1197.

PARK SW, SEO SH, CHANG MB, SHIN IS AND PAIK IK. 2009. Evaluation of soybean oil as a lipid source for pig diets. Asian Austral J Anim 22: 1311-1319. 
PUPA JMR. 2004. Óleos e gorduras na alimentação de aves e suínos. R Eletron Nutritime 1: 69-73.

RABER MR, RIBEIRO AML, KESSLER AM AND ARNAIZ V. 2009. Suplementação de glicerol ou de lecitina em diferentes níveis de ácidos graxos livres em dietas para frangos de corte. Ciênc Anim Bras 10: 745-753.

REIS DE SOUZA T, PEINIAU J, MOUNIER A AND AUMAITRE A. 1995. Effect of addition of tallow and lecithin in the diet of weanling piglets on the apparent total tract and ileal digestibility of fat and fatty acids. Anim Feed Sci Tech 52: 77-91.

ROSTAGNO HS, ALBINO LFT, DONZELE JL, GOMES PC, OLIVEIRA RF, LOPES DC, FERREIRA AS AND
BARRETO SLT. 2011. Tabelas brasileiras para aves e suínos: composição de alimentos e exigências nutricionais. Viçosa: Universidade Federal de Viçosa, 252 p.

SAKOMURA NK AND ROSTAGNO HS. 2007. Métodos experimentais em nutrição de monogástricos. Jaboticabal: FUNEP, $300 \mathrm{p}$.

SOARES M AND LOPEZ-BOTE CJ. 2002. Effects of dietary lecithin and fat unsaturation on nutrient utilization in weaned piglets. Anim Feed Sci Tech 95: 169-177.

VAN KEULEN J AND YOUNG BA. 1977. Evaluation of acid insoluble ash a natural markers in ruminant digestibility studies. J Ani Sci 44:282-287. 